\title{
Development of Optimum Operating Conditions for Quality Attributes in Deep-Fat Frying of Dodo Produced from Plantain Using Response Surface Methodology
}

\author{
James Abiodun Adeyanju1 ${ }^{*}$, John Oluranti Olajide1, Adeyemi Akinbode Adedeji² \\ ${ }^{1}$ Department of Food Science and Engineering, Ladoke Akintola University of Technology, Ogbomoso, Nigeria \\ ${ }^{2}$ Department of Biosystems and Agricultural Engineering, University of Kentucky, Lexington, KY, USA \\ Email: *jaadeyanju@lautech.edu.ng
}

How to cite this paper: Adeyanju, J.A., Olajide, J.O. and Adedeji, A.A. (2016) Development of Optimum Operating Conditions for Quality Attributes in Deep-Fat Frying of Dodo Produced from Plantain Using Response Surface Methodology. Food and Nutrition Sciences, 7, 1423-1433. http://dx.doi.org/10.4236/fns.2016.714129

Received: September 1, 2016 Accepted: December 27, 2016 Published: December 30, 2016

Copyright $\odot 2016$ by authors and Scientific Research Publishing Inc. This work is licensed under the Creative Commons Attribution International License (CC BY 4.0).

http://creativecommons.org/licenses/by/4.0/

\begin{abstract}
Response surface methodology involving historical data design has been successfully developed with the aim of predicting optimum operating conditions for dodo fried from plantain. Frying temperature and time were 150, 160, 170, 180 and $190^{\circ} \mathrm{C}$ and $2.0,2.5,3.0,3.5$ and $4.0 \mathrm{~min}$ respectively. The parameters analyzed included moisture content, oil content, texture and change in colour. The fitted functions were optimized for moisture content, oil content, texture and change in colour in order to obtain a product with the acceptable quality attributes. Frying conditions had significant $(\mathrm{p}<0.05)$ effects on the quality attributes. Coefficients of determination $\left(R^{2}\right)$ of the generated models ranged from 0.91 to 0.99 . Optimum frying condition was $177.51^{\circ} \mathrm{C}$ for $2.10 \mathrm{~min}$. This gave $14.16 \%$ moisture content, $1.54 \%$ oil content, $2.93 \mathrm{~N}$ texture and 40.89 change in colour. Desirability of 0.7 was obtained for optimum conditions. Therefore, the estimated response surface model can be used to optimize the frying process of dodo fried from plantain.
\end{abstract}

\section{Keywords}

Plantain, Frying Process, Moisture Content, Oil Content, Optimization

\section{Introduction}

Plantain (Musa parasidiaca AAB) is major food crops in the humid and sub-humid parts of Africa. It is a major source of energy for millions of people in Africa [1]. Nutritionally, it constitutes a rich energy source, with carbohydrates accounting for $32 \%$ of 
fruit weight for plantain and is rich in vitamins $\mathrm{A}, \mathrm{B}_{6}, \mathrm{C}$, minerals and dietary fibre [2] [3]. The dense calorific content together with nutritional quality makes plantain one of the most significant and commonly consumed staple foods in Nigeria [4] [5]. They contribute appreciably to food security and provide more than $25 \%$ and $10 \%$ of the daily intake of carbohydrates and calories for more than 70 million people in Sub-Saharan Africa [6].

Plantain is commonly consumed in fried form in Nigeria. Very small quantity is converted into flour for porridge making. Others may be eaten either in the form of unripe deep-fat fried snack with crunchy feel called Ipekere or the fully ripe oil fried staple called Dodo or the overripe deep-fat fried snack called Dodo-Ikire. Fried foods generally have been known to contain high calories because of fat absorption. Fried plantain products remain popular in spite of all the health issues associated with high intake of dietary fibre. This is attributed to the unique textural and quality characteristics imparted by frying. Consumers' knowledge of health implications of high calorie has necessitated the resolve by food manufacturers to seek means to optimize the process for minimal fat absorption while the desired qualities are preserved.

One of the oldest and most popular cooking methods of preservation is frying. Deep-Fat Frying (DFF) is a method to produce dried food where an edible fat heated above the boiling point of water serves as the heat transfer medium, fat also migrates into the food, providing nutrients and flavour [7]. It can be considered as a high temperature and a short time process which involves both mass transfer, mainly represented by water loss and oil uptake and heat transfer [8]. Therefore, DFF is often selected as a method for creating unique flavour, colour and texture in processed foods [9] [10]. The disadvantages of DFF which include surface darkening and many adverse reactions take place during frying because of high temperature.

Response Surface Methodology (RSM) is an important technique in optimization process. It is a collection of statistical and mathematical techniques useful for developing, improving and optimizing processes in which a response of interest is influenced by several variables and the objective is to optimize the process [11]. RSM has important application in the design, development and formulation of new products, as well as in the improvement of existing product design. The oil temperature and frying time have been shown as major variables controlling DFF operation [12] [13]. It is important to find an appropriate processing condition for deep fried dodo with high quality attributes. This work therefore aimed at optimizing the DFF processing conditions of dodo using RSM with the purpose of achieving high quality attributes.

\section{Materials and Methods}

\subsection{Materials}

Matured plantain fruits harvested at green stage were obtained from a local farm in Ogbomoso and identified in the Department of Crop and Environmental Protection, LAUTECH, Ogbomoso, Oyo State, Nigeria. Refined vegetable oil commonly used for 
frying was purchased from Ace Supermarket, Ogbomoso, Nigeria.

\subsection{Sample Preparation}

Fresh, matured plantains were kept at $30^{\circ} \mathrm{C} \pm 2{ }^{\circ} \mathrm{C}$ and allowed to ripen slowly until they reached the desired yellow stage of ripeness using colour index chart according to Aurore et al. [14]. The fruits were manually peeled and sliced with a knife. The pulps were sliced to discs of thickness $5.0 \mathrm{~mm}$. The discs were measured with a sliding calliper and any incorrectly sliced discs were rejected.

\subsection{Experimental Design}

Response surface methodology using historical data design was used to study the effect of frying temperature and time on the quality characteristics of dodo. The variables considered were frying temperature $\left(X_{1}\right)$ and time $\left(X_{2}\right)$ while the responses were moisture content $(M C)$, oil content $(O C)$, texture $(T)$ and change in colour $(\triangle E)$.

\subsection{Frying Operation}

The fryer was filled with $2.5 \mathrm{~L}$ of oil and equipped with a $2 \mathrm{~kW}$. Plantain slices to oil ratio was kept at 1:5 by volume. Plantains were fried at temperature in the range of $150^{\circ} \mathrm{C}$ to $190^{\circ} \mathrm{C}$ and time ranging from $2 \mathrm{~min}$ to $4 \mathrm{~min}$. Excess oil was removed by shaking the baskets manually and the chips were placed on a rack to cool after frying. Samples were stored in sealed, low density polyethylene bags and kept at room temperature until analyses were performed.

\subsection{Analysis of Sample}

\subsubsection{Moisture Content}

The sample ( $5 \mathrm{~g}$ ) was weighed into a pre-weighed moisture dish. The dish plus sample taken was transferred into the oven pre-set at $105^{\circ} \mathrm{C}$ to dry to a constant weight for 24 hours overnight. At the end of the 24 hours, the dish plus sample was removed from the oven and transferred to desiccator, cooled for $30 \mathrm{~min}$ and weighed [15].

\subsubsection{Fat Content}

Oil content was determined following the AOAC [15] method. Fried plantain samples were ground using a grinder. Five gram of sample was weighed into thimbles for fat extraction in a solvent extractor (SER 148, Velp Scientifica, Usmate, Italy) using petroleum ether. Oil content was determined as the ratio of the mass of extracted fat and dry matter of the sample. The extraction process took approximately two hours.

\subsubsection{Texture}

The texture of fried plantain samples were determined using a universal testing machine (Model 500, Testometric AX, Rochdale, Lancashire, England) equipped with a 1 $\mathrm{kN}$ load cell. The cylindrical probe used in the test was made of stainless steel with 2 $\mathrm{mm}$ diameter and $30 \mathrm{~mm}$ height. The machine was calibrated with a $1 \mathrm{~kg}$ weight. The force-displacement data were collected at the rate of 10 points per second. The probe 
was moved at a speed of $100 \mathrm{~mm} / \mathrm{min}$ and allowed to penetrate $20 \mathrm{~mm}$ into the sample in a 2-cycle test [16].

\subsubsection{Colour}

Colour variables $\left(L^{*}, a^{*}\right.$ and $\left.b^{*}\right)$ were measured using a colorimeter (Colour Tec-PCM, Hunterdon, NJ) as described by Krokida et al. [17]. The instrument was standardized and the samples were placed in the sample holder. Samples were scanned at different locations to determine lightness $\left(L^{*}\right)$, redness $\left(a^{*}\right)$ and yellowness $\left(b^{*}\right)$ variables. Colour measurement was determined in triplicates. The change in colour $(\Delta E)$ of dodo was calculated using Equation (1) [18].

$$
\Delta E=\sqrt{\Delta L^{* 2}+\Delta a^{* 2}+\Delta b^{* 2}}
$$

\subsection{Modeling and Optimization}

Regression models were developed for the quality attributes of dodo as a function of the two process variables. The Design Expert software version 9.0.3.1 was used to analyze the frying data for developing response equations, analysis of variance (ANOVA), generate surface plots and determine optimum frying conditions using its optimization toolbox. Statistical significance of the terms in the regression equations was tested for errors and test of significance considering probability at confidence limits with $\mathrm{p}<0.05$ was used for ANOVA.

\section{Results and Discussion}

\subsection{Model Parameters for Fried Plantain (Dodo)}

The DFF process of dodo and their corresponding responses results are presented in Table 1. Multiple regression and correlation analysis are used as tools for assessment of the effects of two or more independent variables on the dependent variables. The probability $\mathrm{F}$ value and $\mathrm{p}$-value were used as a tool to check the significance of each of the coefficients in Table 2. A large magnitude of the $\mathrm{F}$ value and smaller $\mathrm{p}$-value denoted greater significance of the corresponding coefficient [19]. The coefficients of determination $\left(\mathrm{R}^{2}\right)$ for the responses moisture content, oil content, texture and change in colour are $0.93,0.99,0.99$ and 0.91 , respectively. The values are quite high for response surfaces and indicated that the fitted quadratic models accounted for more than $90 \%$ of the variance in the experimental data, which were found to be highly significant. Based on p-values, the only regression coefficients significant at $95 \%$ and $99 \%$ levels were selected for developing the models.

In order to evaluate the adequacy and consistency of the models, ANOVA was conducted using F-statistic. The F-value for moisture content (53.36), oil content (2096.38), texture (381.13) and colour (39.28) were significant at 95\% confidence level (Table 2). Therefore, it can be concluded that the selected models adequately represent the data for moisture content, oil content, texture and colour. The empirical models obtained for the quality attributes of dodo were stated as Equations (2)-(5). 
Table 1. The experimental design and obtained values of the responses.

\begin{tabular}{|c|c|c|c|c|c|c|}
\hline \multirow{2}{*}{ Run } & \multicolumn{2}{|c|}{ Factors } & \multicolumn{4}{|c|}{ Responses } \\
\hline & $X_{1} \quad\left({ }^{\circ} \mathrm{C}\right)$ & $X_{2} \quad(\min )$ & $M C(\%)$ & $O C(\%)$ & $T(\mathrm{~N})$ & $\Delta E$ \\
\hline 1 & 150.00 & 2.00 & 14.28 & 1.53 & 2.96 & 52.96 \\
\hline 2 & 160.00 & 2.00 & 14.23 & 1.54 & 2.68 & 49.32 \\
\hline 3 & 170.00 & 2.00 & 14.17 & 1.54 & 2.82 & 43.54 \\
\hline 4 & 180.00 & 2.00 & 14.16 & 1.53 & 3.04 & 41.85 \\
\hline 5 & 190.00 & 2.00 & 14.15 & 1.52 & 3.47 & 33.73 \\
\hline 6 & 150.00 & 2.50 & 14.25 & 1.55 & 2.93 & 52.56 \\
\hline 7 & 160.00 & 2.50 & 14.19 & 1.56 & 2.76 & 49.15 \\
\hline 8 & 170.00 & 2.50 & 14.21 & 1.56 & 2.70 & 43.71 \\
\hline 9 & 180.00 & 2.50 & 14.12 & 1.57 & 3.01 & 40.18 \\
\hline 10 & 190.00 & 2.50 & 14.12 & 1.54 & 3.43 & 41.32 \\
\hline 11 & 150.00 & 3.00 & 14.23 & 1.56 & 3.01 & 50.23 \\
\hline 12 & 160.00 & 3.00 & 14.21 & 1.57 & 2.73 & 46.56 \\
\hline 13 & 170.00 & 3.00 & 14.12 & 1.58 & 2.86 & 37.96 \\
\hline 14 & 180.00 & 3.00 & 14.09 & 1.58 & 3.08 & 37.86 \\
\hline 15 & 190.00 & 3.00 & 14.09 & 1.57 & 3.50 & 38.06 \\
\hline 16 & 150.00 & 3.50 & 14.22 & 1.58 & 3.19 & 48.56 \\
\hline 17 & 160.00 & 3.50 & 14.21 & 1.59 & 2.92 & 44.49 \\
\hline 18 & 170.00 & 3.50 & 14.10 & 1.61 & 3.04 & 40.89 \\
\hline 19 & 180.00 & 3.50 & 14.08 & 1.61 & 3.26 & 33.32 \\
\hline 20 & 190.00 & 3.50 & 14.07 & 1.60 & 3.68 & 35.15 \\
\hline 21 & 150.00 & 4.00 & 14.21 & 1.60 & 3.48 & 47.93 \\
\hline 22 & 160.00 & 4.00 & 14.13 & 1.60 & 3.30 & 42.88 \\
\hline 23 & 170.00 & 4.00 & 14.08 & 1.63 & 3.32 & 36.33 \\
\hline 24 & 180.00 & 4.00 & 14.05 & 1.63 & 3.54 & 35.01 \\
\hline 25 & 190.00 & 4.00 & 14.05 & 1.62 & 3.96 & 33.99 \\
\hline
\end{tabular}

Where: $M C=$ Moisture content (\%), $O C=$ Oil content (\%), $T=$ Texture (N) and $\Delta E=$ Change in colour.

$$
\begin{gathered}
M C=16.87-0.02 X_{1}+0.04 X_{2}+7.62 E-5 X_{1}^{2}-1.33 E-3 X_{2}^{2}-4.90 E-0.04 X_{1} X_{2} \\
O C=0.37+0.01 X_{1}-0.03 X_{2}-4.48 E-5 X_{1}^{2}-3.98 E-4 X_{2}^{2}+4.84 E-4 X_{1} X_{2} \\
T=32.25-0.34 X_{1}-0.98 X_{2}+1.06 E-3 X_{1}^{2}+0.22 X_{2}^{2}-5.50 E-4 X_{1} X_{2} \\
\Delta E=298.61-2.56 X_{1}-2.36 X_{2}+6.20 E-3 X_{1}^{2}-0.89 X_{2}^{2}+0.02 X_{1} X_{2}
\end{gathered}
$$

The coefficient of the regression equations for the measured responses, the linear, quadratic and interaction terms of the selected variables were evaluated and values were shown in Table 2. As reflected in Equations (2)-(5), the sign and magnitude of the coefficients indicate the effect of variable on the response. Negative sign of the coefficient indicate decrease in dependent variable when the value of that independent variable is 
Table 2. Analysis of variance and coefficients for the prediction models.

\begin{tabular}{|c|c|c|c|c|c|c|}
\hline Responses & Sources of variance & Sum of squares & $\mathrm{DF}$ & Mean squares & F-value & p-value \\
\hline \multirow{8}{*}{$M C$} & Model & 0.1056 & 5 & 0.0211 & 53.3568 & $0.0001^{\star}$ \\
\hline & $X_{1}$ & 0.0737 & 1 & 0.0737 & 186.405 & $0.0001^{\star}$ \\
\hline & $X_{2}$ & 0.0271 & 1 & 0.0271 & 68.5544 & $0.0001^{*}$ \\
\hline & $X_{1}^{2}$ & 0.0040 & 1 & 0.0040 & 10.2862 & $0.0046^{*}$ \\
\hline & $X_{2}^{2}$ & $7.81 \mathrm{E}-6$ & 1 & $7.81 \mathrm{E}-6$ & 0.0197 & 0.8898 \\
\hline & $X_{1} X_{2}$ & 0.0006 & 1 & 0.0006 & 1.5182 & 0.2329 \\
\hline & Residual & 0.0075 & 19 & 0.0003 & & \\
\hline & Total & 0.1131 & 24 & & & \\
\hline \multirow[t]{8}{*}{$O C$} & Model & 0.0257 & 5 & 0.0051 & 2096.384 & $0.0001^{\star}$ \\
\hline & $X_{1}$ & 0.0002 & 1 & 0.0002 & 87.5263 & $0.0001^{*}$ \\
\hline & $X_{2}$ & 0.0235 & 1 & 0.0235 & 9582.882 & $0.0001^{*}$ \\
\hline & $X_{2}^{2}$ & 0.0014 & 1 & 0.0014 & 572.790 & $0.0001^{\star}$ \\
\hline & $X_{2}^{2}$ & $6.93 \mathrm{E}-7$ & 1 & $6.93 \mathrm{E}-7$ & 0.2819 & 0.6016 \\
\hline & $X_{1} X_{2}$ & 0.0005 & 1 & 0.0005 & 238.439 & $0.0001^{\star}$ \\
\hline & Residual & $4.67 \mathrm{E}-5$ & 19 & $2.46 \mathrm{E}-6$ & & \\
\hline & Total & 0.0258 & 24 & & & \\
\hline \multirow[t]{8}{*}{$T$} & Model & 2.6853 & 5 & 0.5370 & 381.1286 & $0.0001^{*}$ \\
\hline & $X_{1}$ & 0.8274 & 1 & 0.8274 & 587.1978 & $0.0001^{\star}$ \\
\hline & $X_{2}$ & 0.8498 & 1 & 0.8498 & 603.1173 & $0.0001^{*}$ \\
\hline & $X_{2}^{2}$ & 0.7878 & 1 & 0.7878 & 559.0968 & $0.0001^{\star}$ \\
\hline & $X_{2}^{2}$ & 0.2193 & 1 & 0.2193 & 155.6933 & $0.0001^{\star}$ \\
\hline & $X_{1} X_{2}$ & 0.0007 & 1 & 0.0007 & 0.5376 & 0.4724 \\
\hline & Residual & 0.0267 & 19 & 0.0014 & & \\
\hline & Total & 2.7120 & 24 & & & \\
\hline \multirow[t]{8}{*}{$\Delta E$} & Model & 823.1752 & 5 & 164.6350 & 39.2821 & $0.0001^{*}$ \\
\hline & $X_{1}$ & 678.1304 & 1 & 678.1304 & 161.803 & $0.0001^{*}$ \\
\hline & $X_{2}$ & 112.6736 & 1 & 112.6736 & 26.8841 & $0.0001^{\star}$ \\
\hline & $X_{2}^{2}$ & 26.9681 & 1 & 26.9681 & 6.43463 & $0.0201^{*}$ \\
\hline & $X_{2}^{2}$ & 3.4813 & 1 & 3.4813 & 0.8306 & 0.3735 \\
\hline & $X_{1} X_{2}$ & 1.9217 & 1 & 1.9217 & 0.4585 & 0.5065 \\
\hline & Residual & 79.6306 & 19 & 4.1910 & & \\
\hline & Total & 902.8058 & 24 & & & \\
\hline
\end{tabular}

${ }^{*} \mathrm{p}<0.05$ indicates statistical significance.

increased while positive sign of the coefficient indicate increase in dependent variable when the value of that independent variable is increased. Significant interaction suggests that the level of one of the interaction variables can be increased while that of other decreased for constant value of the response.

The results of the moisture content of dodo showed that two linear $\left(X_{1}, X_{2}\right)$ fac- 
tors, two quadratic $\left(X_{1}^{2}, X_{2}^{2}\right)$ factors and one interaction $\left(X_{1} X_{2}\right)$ term were significant at $\mathrm{p}<0.05$. For the oil content, it was shown from the analysis that two linear $\left(X_{1}\right.$, $\left.X_{2}\right)$ factors, one quadratic $\left(X_{1}^{2}\right)$ and one interaction $\left(X_{1} X_{2}\right)$ term were significant and one quadratic term $\left(X_{2}^{2}\right)$ was not significant. In the case of the texture of the dodo produced, the two terms were linear $\left(X_{1}, X_{2}\right)$, the two quadratic $\left(X_{1}^{2}, X_{2}^{2}\right)$ were significant terms and one interaction term $\left(X_{1}, X_{2}\right)$ was not significant. The results of change in colour of the dodo showed that two linear $\left(X_{1}, X_{2}\right)$ factors, one quadratic $\left(X_{1}^{2}\right)$ factor were significant while one quadratic factor $\left(X_{2}^{2}\right)$ and one interaction $\left(X_{1} X_{2}\right)$ term were not significant.

\subsection{Effect of Process Variables on the Quality Attributes of Dodo}

Figure 1 showed the effect of interaction of frying temperature and time on moisture content. The moisture content ranged between $14.05 \%$ and $14.28 \%$. It was observed that increase in temperature resulted in reduced moisture content in the dodo fried from plantain slices. This indicated that the moisture content was affected by frying temperature and time. The moisture content in fried products can affect the textural properties, as well as the storage quality. The values obtained were similar with those obtained by earlier studies on thermal sensitivity of some plantain micronutrients during DFF [20].

The effect of interaction of frying temperature and time on oil content is shown in Figure 2. The oil content of the dodo was between the values of $1.52 \%$ and $1.63 \%$. Contour plot showed that as the frying temperature and time of the process increased the oil content of dodo increased. This increase in oil content coincided with the period of moisture evaporation from the fried plantain. The changes in the water and oil contents of dodo are in agreement with the works of [21] [22].

Figure 3 showed the effect of interaction of frying temperature and time on texture

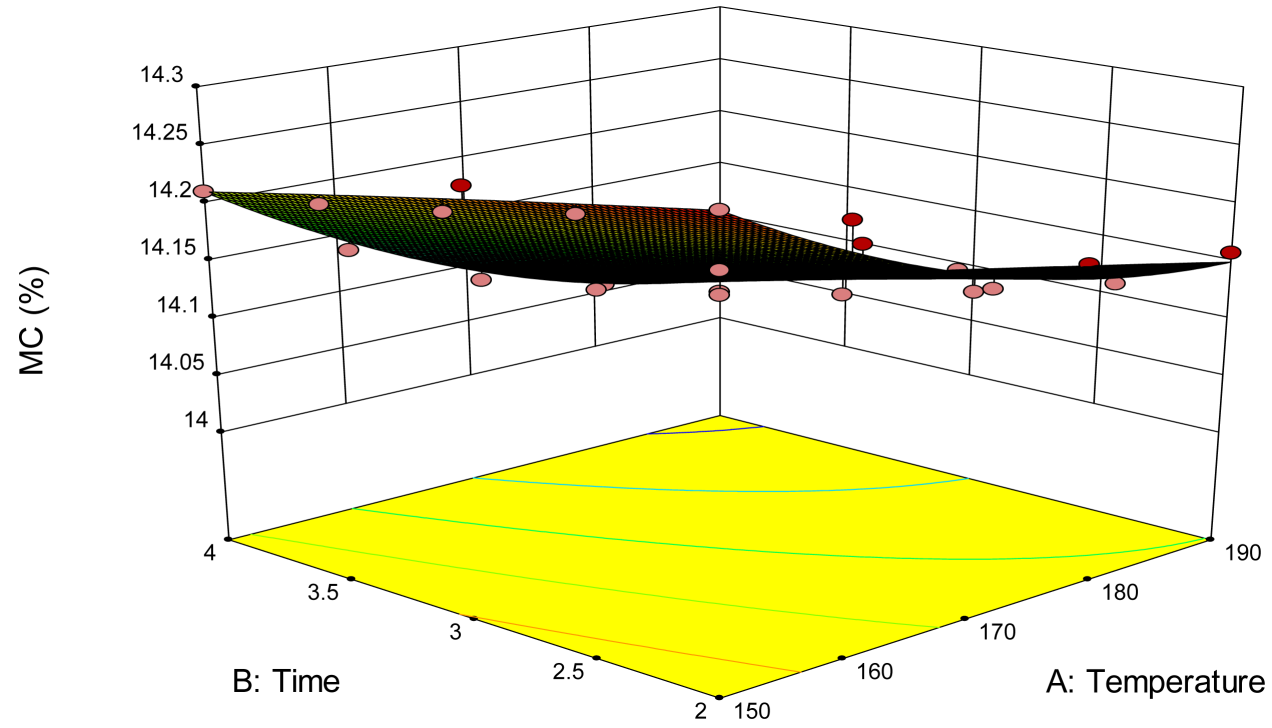

Figure 1. The surface plot for moisture content of dodo as affected by frying temperature and time. 


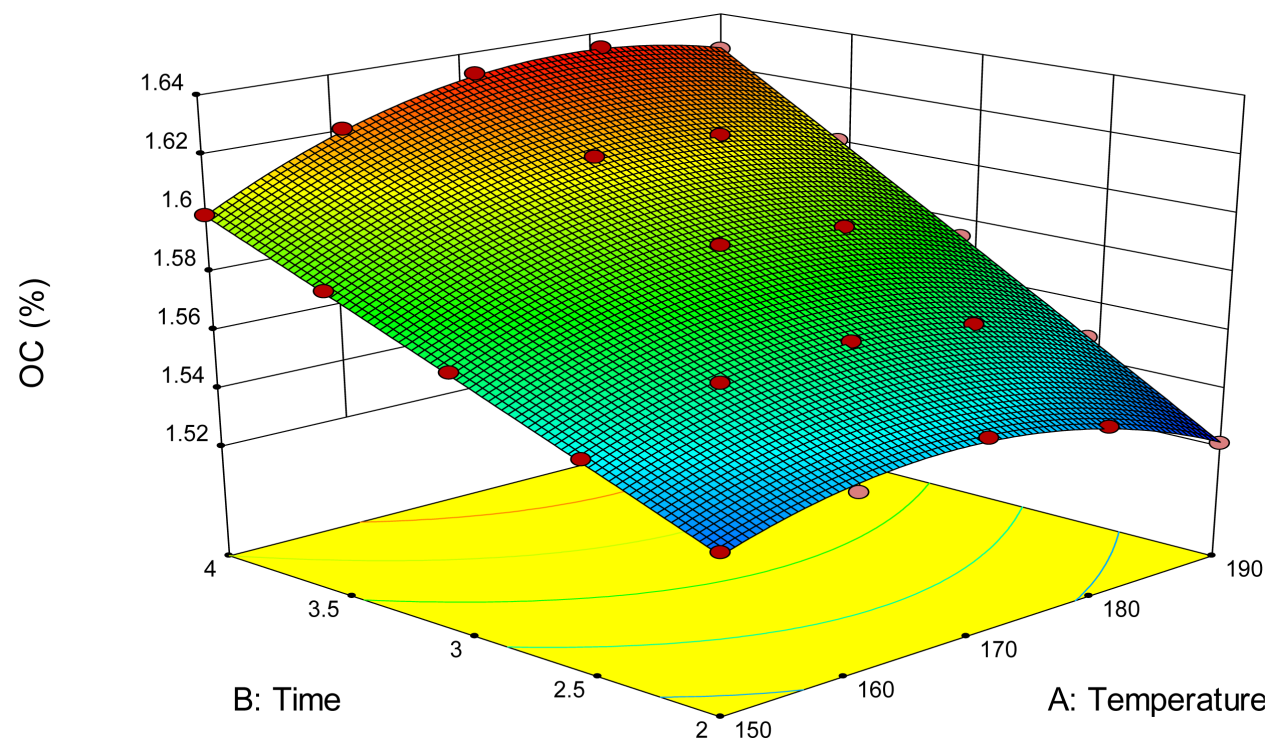

Figure 2. The surface plot for oil content of dodo as affected by frying temperature and time.

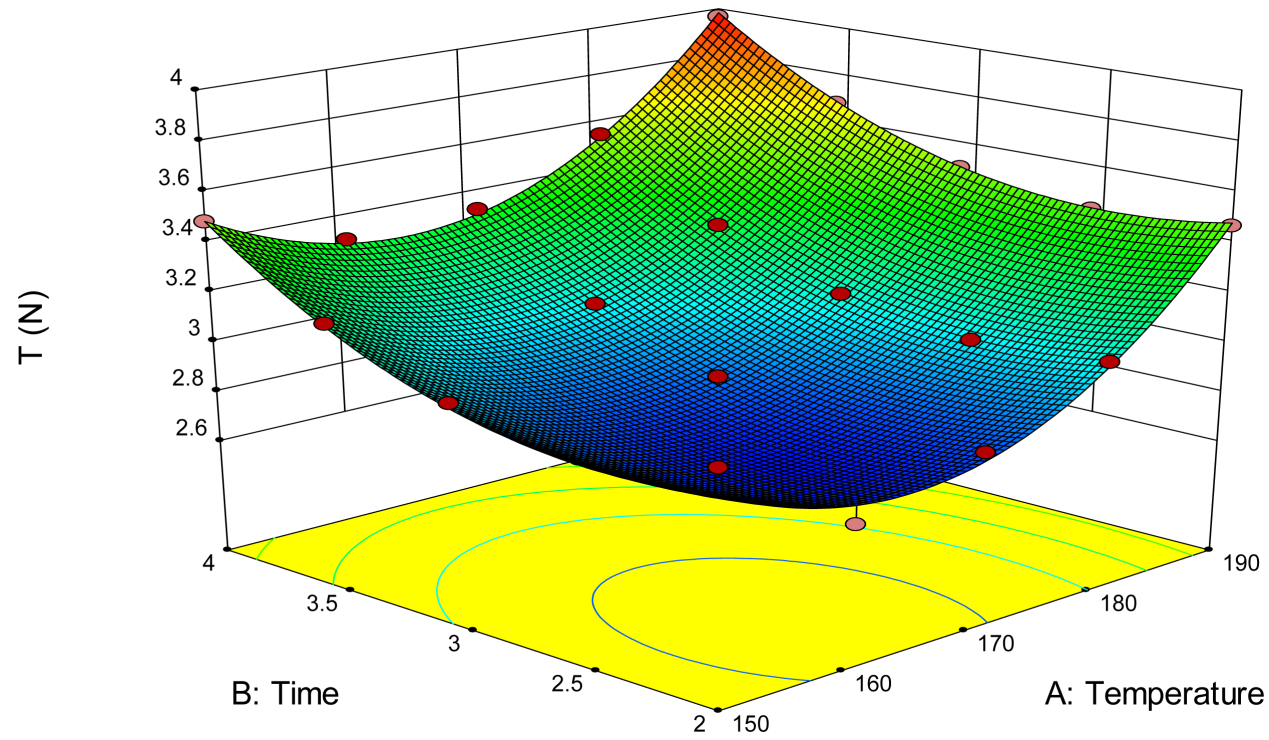

Figure 3. The surface plot for texture of dodo as affected by frying temperature and time.

of dodo. The texture varied between 2.96 to $3.96 \mathrm{~N}$. Textural attribute is critical in determining acceptance of foods; therefore, a puncture test of the dodo was carried out. There was decreased in the texture of dodo as the frying temperature and time increased. The texture of fried products has been reported to depend on raw materials, processing conditions and should be crispy, mealy, and firm during frying [23] [24]. This finding agreed with report of [25] on vacuum frying of doughnuts who observed that the texture was directly related to frying temperature and time.

The effect of interaction of temperature and time on change in colour is shown in Figure 4. The change in colour was between 33.33 and 52.96. The $\Delta E$ of dodo decreased progressively as the frying temperature and time increased. The implication is 


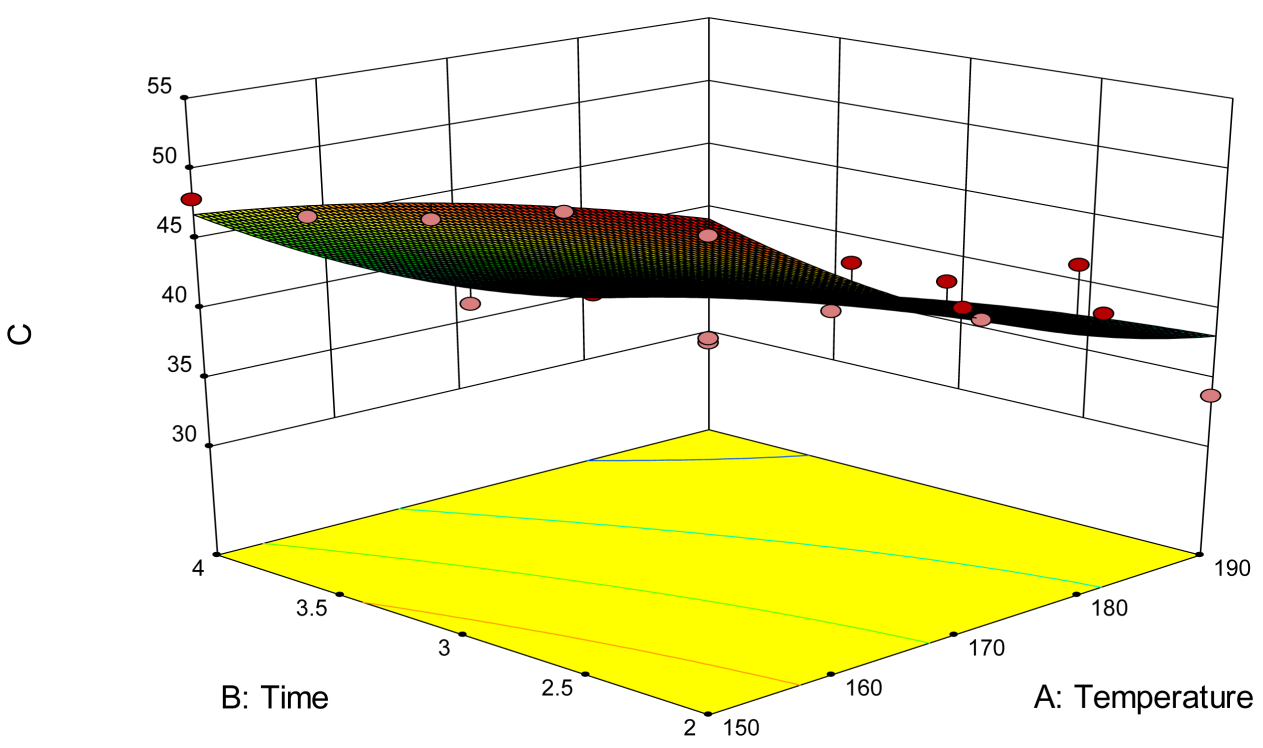

Figure 4. The surface plot for colour of dodo as affected by frying temperature and frying time.

that higher Hunter $\Delta E$ values will lead to lower colour quality on the surface of $d o d o$. It was observed that an increase in temperature led to a significant formation of brown products. A change in colour of dodo to dark is usually due to non-enzymatic browning at higher temperatures [26]. The similar results were obtained by Moreira et al. [27] on vacuum frying of potato chips.

\section{Conclusion}

The models $(M C, O C, T$ and $\triangle E$ ) were useful for indicating the direction in which to change variables in order to minimize moisture content, fat content, texture and change in colour. Based on the above findings, an optimization study was performed to evaluate the optimal operating conditions for individual responses. The optimum quality characteristics values obtained are $14.16 \%, 1.54 \%, 2.93 \mathrm{~N}$ and 40.89 for moisture content, oil content, texture and change in colour, respectively at $177.51^{\circ} \mathrm{C}$ and $2.10 \mathrm{mi}-$ nutes, having a desirability of 0.70 . Therefore, the estimated response surface model can be used to optimize the frying process of dodo fried from plantain.

\section{References}

[1] John, P. and Marchal, J. (1995) Ripening and Biochemistry of the Fruit. In: Gowen, S.R., Ed., Bananas and Plantains, Chapman and Hall, London, 122-156. https://doi.org/10.1007/978-94-011-0737-2 15

[2] Chandler, S. (1995) The Nutritional Value of Bananas. In: Gowen, S.R., Ed., Bananas and Plantains, Chapman and Hall, London, 74-89. https://doi.org/10.1007/978-94-011-0737-2 16

[3] Honfo, F.G. and Hell, K., Coulibaly, O. and Tenkouano, A. (2007) Micronutrient Value and Contribution of Plantain-Derived Foods to Daily Intakes of Iron, Zinc, and b-Carotene in Southern Nigeria. Info-Musa, 16, 2-6.

[4] Ajayi, A.R. and Aneke, M.O. (2002) Consumption and Expenditure Patterns of Banana and 
Plantain Consumers in Nsukka Urban, Nigeria. Info-Musa, 11, 50-53.

[5] Lusty, C., Akyeampong, E., Davey, M.W., Ngoh, N.G. and Markham, R. (2006) A Staple Food with Nutritious Appeal. Info-Musa, 15, 39-43.

[6] IITA (2000) Improving Plantain and Banana Based. International Institute of Tropical Agriculture, Project 2, Annual Report, Ibadan, 67.

[7] Fan, F.L., Zhang, M. and Mujumdar, A.S. (2005) Vacuum Frying of Carrot Chips. Drying Technology, 23, 645-656. https://doi.org/10.1081/DRT-200054159

[8] Vitrac, O., Dufour, D., Trystram, G. and Raoult-Wack, A. (2002) Characterization of Heat and Mass Transfer during Deep-Fat Frying and Its Effect on Cassava Chip Quality. Journal of Food Engineering, 53, 161-176. https://doi.org/10.1016/S0260-8774(01)00153-4

[9] Mellema, M. (2003) Mechanism and Reduction of Fat Uptake in Deep-Fat Fried Foods. Trends in Food Science and Technology, 14, 364-373. https://doi.org/10.1016/S0924-2244(03)00050-5

[10] Pedreschi, F. (2012) Frying of Potatoes: Physical, Chemical and Microstructural Changes. Drying Technology, 30, 707-725. https://doi.org/10.1080/07373937.2012.663845

[11] Garayo, J. and Moreira, R. (2002) Vacuum Frying of Potato Chips. Journal of Food Engineering, 55, 181-191. https://doi.org/10.1016/S0260-8774(02)00062-6

[12] Sulaeman, A., Keeler, L., Giraud, D.W., Taylor, S.L. and Driskell, J.A. (2001) Carotenoid Content and Physicochemical and Sensory Characteristics of Carrot Chips Deep-Fried in Different Oils at Several Temperatures. Journal of Food Science, 66, 1257-1264. https://doi.org/10.1111/j.1365-2621.2001.tb15198.x

[13] Sobukola, O.P., Awonorin, S.O., Sanni, L.O. and Bamiro, F.O. (2008) Deep Fat Frying of Yam Slices: Optimization of Processing Conditions Using Response Surface Methodology. Journal of Food Processing and Preservation, 32, 343-360. https://doi.org/10.1111/j.1745-4549.2008.00183.x

[14] Aurore, G., Berthe, P. and Louis, F. (2009) Bananas, Raw Materials for Making Processed Food Products: A Review. Trends in Food Science and Technology, 20, 78-91. https://doi.org/10.1016/j.tifs.2008.10.003

[15] AOAC (2005) Official Methods of Analysis of the Association of Official Chemists. 18th Edition, Washington DC.

[16] Bourne, M.C. (1979) Theory and Application of the Puncture Test in Food Texture Measurement. In: Sherman, P., Ed., Food Texture and Rheology, Academic Press, London, 95142.

[17] Krokida, M.K., Oreopoulou, V., Maroulis, Z.B. and Marinos-Kouris, D. (2001) Colour Changes during Deep-Fat Frying. Journal of Food Engineering, 48, 219-225.

[18] Hunt, R.W.G. (1991) Measuring Colour. 2nd Edition, Ellis Horwood, New York, 75-76.

[19] Montgomery, D.C. (1997) Response Surface Methods and Other Approaches to Process Optimization. In: Montgomery, D.C., Ed., Design and Analysis of Experiments, John Wiley \& Sons, New York, 427-510.

[20] Avallone, S., Rojas-Gonzalez, J.A., Trystram, G. and Bohuon, P. (2009) Thermal Sensitivity of Some Plantain Micronutrients during Deep-Fat Frying. Journal of Food Science, 74, C339-C347. https://doi.org/10.1111/j.1750-3841.2009.01155.x

[21] Rice, P. and Gamble, M.H. (1989) Technical Note: Modelling Moisture Loss during Potato Slice Frying. International Journal of Food Science and Technology, 24, 183-187. https://doi.org/10.1111/j.1365-2621.1989.tb00632.x

[22] Krokida, M.K. and Orepoulou, V. (2000) Water Loss and Oil Uptake as a Function of Fry- 
ing Time. Journal of Food Engineering, 44, 39-46.

https://doi.org/10.1016/S0260-8774(99)00163-6

[23] Krokida, M.K., Oreopoulou, V., Maroulis, Z.B. and Kouris, D.M. (2001) Effect of Pre-Drying on the Quality of French Fries. Journal of Food Engineering, 49, 347-354.

https://doi.org/10.1016/S0260-8774(00)00233-8

[24] Nourian F. and Ramaswamy, H.S. (2003) Kinetics of Quality Changes during Cooking and Frying of Potatoes: Part 1. Texture. Journal of Food Process Engineering, 26, 377-394 https://doi.org/10.1111/j.1745-4530.2003.tb00608.x

[25] Tan, K.J. and Mittal, G.S. (2006) Physicochemical Properties Changes of Doughnuts during Vacuum Frying. International Journal of Food Properties, 9, 85-98.

https://doi.org/10.1080/10942910500473947

[26] Shyu, S. and Hwang, L. (2001) Effects of Processing Conditions on the Quality of Vacuum Fried Apple Chips. Food Research International, 34, 133-142.

https://doi.org/10.1016/S0963-9969(00)00141-1

[27] Moreira, R.G., Da Silva, P.F. and Gomes, C. (2009) The Effect of a De-Oiling Mechanism on the Production of High Quality Vacuum Fried Potato Chips. Journal of Food Engineering, 92, 297-304. https://doi.org/10.1016/j.jfoodeng.2008.11.012

Submit or recommend next manuscript to SCIRP and we will provide best service for you:

Accepting pre-submission inquiries through Email, Facebook, LinkedIn, Twitter, etc.

A wide selection of journals (inclusive of 9 subjects, more than 200 journals)

Providing 24-hour high-quality service

User-friendly online submission system

Fair and swift peer-review system

Efficient typesetting and proofreading procedure

Display of the result of downloads and visits, as well as the number of cited articles

Maximum dissemination of your research work

Submit your manuscript at: http://papersubmission.scirp.org/

Or contact fns@scirp.org 